\title{
A catastrophic meltwater flood event and the formation of the Hudson Shelf Valley
}

\author{
E. Robert Thieler ${ }^{\mathrm{a}, *}$, Bradford Butman ${ }^{\mathrm{a}}$, William C. Schwab ${ }^{\mathrm{a}}$, Mead A. Allison ${ }^{\mathrm{b}}$, \\ Neal W. Driscoll ${ }^{\text {c }}$, Jeffrey P. Donnelly ${ }^{\mathrm{d}}$, Elazar Uchupi ${ }^{\mathrm{d}}$ \\ ${ }^{\text {a }}$ U.S. Geological Survey, 384 Woods Hole Rd., Woods Hole, MA 02543, USA \\ ${ }^{\mathrm{b}}$ Department of Earth and Environmental Sciences, Tulane University, New Orleans, LA 70118, USA \\ ${ }^{\mathrm{c}}$ Scripps Institution of Oceanography, La Jolla, CA 92093, USA \\ d Department of Geology and Geophysics, Woods Hole Oceanographic Institution, Woods Hole, MA 02543, USA
}

Received 26 August 2004; accepted 17 October 2006

\begin{abstract}
The Hudson Shelf Valley (HSV) is the largest physiographic feature on the U.S. mid-Atlantic continental shelf. The 150-km long valley is the submerged extension of the ancestral Hudson River Valley that connects to the Hudson Canyon. Unlike other incised valleys on the mid-Atlantic shelf, it has not been infilled with sediment during the Holocene. Analyses of multibeam bathymetry, acoustic backscatter intensity, and high-resolution seismic reflection profiles reveal morphologic and stratigraphic evidence for a catastrophic meltwater flood event that formed the modern HSV. The valley and its distal deposits record a discrete flood event that carved $15-\mathrm{m}$ high banks, formed a $120-\mathrm{km}^{2}$ field of 3- to 6-m high bedforms, and deposited a subaqueous delta on the outer shelf. The HSV is inferred to have been carved initially by precipitation and meltwater runoff during the advance of the Laurentide Ice Sheet, and later by the drainage of early proglacial lakes through stable spillways. A flood resulting from the failure of the terminal moraine dam at the Narrows between Staten Island and Long Island, New York, allowed glacial lakes in the Hudson and Ontario basins to drain across the continental shelf. Water level changes in the Hudson River basin associated with the catastrophic drainage of glacial lakes Iroquois, Vermont, and Albany around $11,450{ }^{14} \mathrm{C}$ year BP $(\sim 13,350$ cal BP $)$ may have precipitated dam failure at the Narrows. This $3200 \mathrm{~km}^{3}$ discharge of freshwater entered the North Atlantic proximal to the Gulf Stream and may have affected thermohaline circulation at the onset of the Intra-Allerød Cold Period. Based on bedform characteristics and fluvial morphology in the HSV, the maximum freshwater flux during the flood event is estimated to be $\sim 0.46 \mathrm{~Sv}$ for a duration of $\sim 80$ days.

Published by Elsevier B.V.
\end{abstract}

Keywords: Continental shelf; Glacial lakes; Meltwater; Sea-level rise; Transgression; Wisconsinan

\section{Introduction}

The Hudson River is recognized as playing a significant role in the delivery of freshwater to the North

\footnotetext{
* Corresponding author. Tel.: +1 508457 2350; fax: +1 5084572310

E-mail address: rthieler@usgs.gov (E.R.Thieler).
}

Atlantic during the last deglaciation (Donnelly et al., 2005). Changes in Laurentide Ice Sheet (LIS) meltwater routing between the Mississippi River and eastern outlets (the Hudson and St. Lawrence Rivers) influenced the vigor of Atlantic thermohaline circulation and thereby impacted climate (Broecker et al., 1989; Clark et al., 2001). During deglaciation, the routing of runoff 
from the retreating LIS in eastern North America was controlled by terminal moraines and the position of ice lobes that caused fresh water to be routed into specific drainage basins (Licciardi et al., 1999), where it was often stored temporarily in proglacial lakes. The catastrophic draining of these glacial lakes into the North Atlantic has been proposed as an important influence on thermohaline circulation and climate change (Alley et al., 1997; Barber et al., 1999; Clark et al., 2001; Teller et al., 2002). Modeling studies (Rahmstorf, 1995; Manabe and Stouffer, 1997; Fanning and Weaver, 1997; Ganopolski and Rahmstorf, 2001) further suggest that the location and magnitude of freshwater delivery are critical factors causing changes in North Atlantic thermohaline circulation.

The New York-New Jersey portion of the Atlantic continental shelf has a long history of study that has influenced present understanding of sea-level change and coastal evolution. Most studies have interpreted the depositional and erosional features on this shelf sector in the context of processes acting during and after the Late
Wisconsinan lowstand of sea level. Veatch and Smith (1939) proposed that low scarps present on the shelf were paleo-shorelines, and named them the Nicholls $(\sim-120 \mathrm{~m})$, Franklin $(-110 \mathrm{~m})$, and Fortune $(-50 \mathrm{~m})$ shores. Knebel and Spiker (1977) termed a portion of the Fortune shoreline the Tiger scarp. Dillon and Oldale (1978) assigned ages of 15,000 and $13,000{ }^{14} \mathrm{C}$ year BP to the Nicholls and Franklin shores, based primarily on their relationship to regional sea level during postglacial sea-level rise (Emery and Garrison, 1967; Milliman and Emery, 1968).

Sediment wedges on the continental shelf off southern New York and New Jersey (the outer shelf wedge and the mid-shelf wedge, Fig. 1) have been interpreted as resulting from deposition during the last deglaciation (Ewing et al., 1963; Milliman et al., 1990), and more recently have been reinterpreted to represent deposition from catastrophic failure of glacial lakes (Uchupi et al., 2001; Donnelly et al., 2005).

In this paper, multibeam bathymetry and seismic data are used to understand the evolutionary history of this

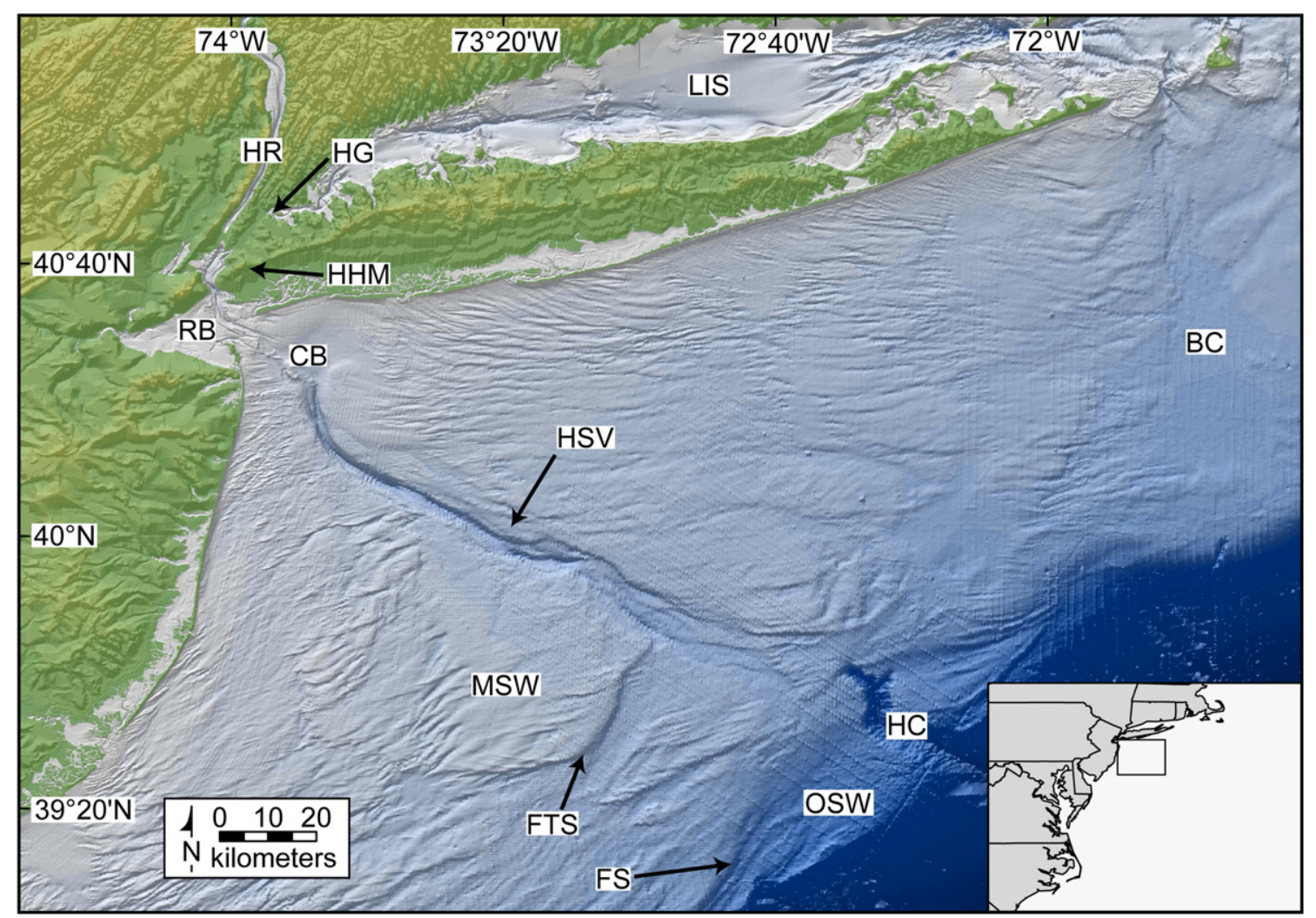

Fig. 1. Shaded relief map of the New York-New Jersey continental shelf showing the location of the Hudson Shelf Valley and other important morphologic features, using topography and bathymetry data from the NOAA Coastal Relief Model. HR=Hudson River; HG=Hell Gate $($ East River); RB=Raritan Bay; HHM=Harbor Hill Moraine; $\mathrm{CB}=$ Christiansen Basin; HSV=Hudson Shelf Valley; $\mathrm{BC}=\mathrm{Block} \mathrm{Channel}$; MSW=Midshelf Wedge; FTS=Fortune/Tiger Shore; FS=Franklin Shore; OSW=Outer Shelf Wedge; HC=Hudson Canyon. 

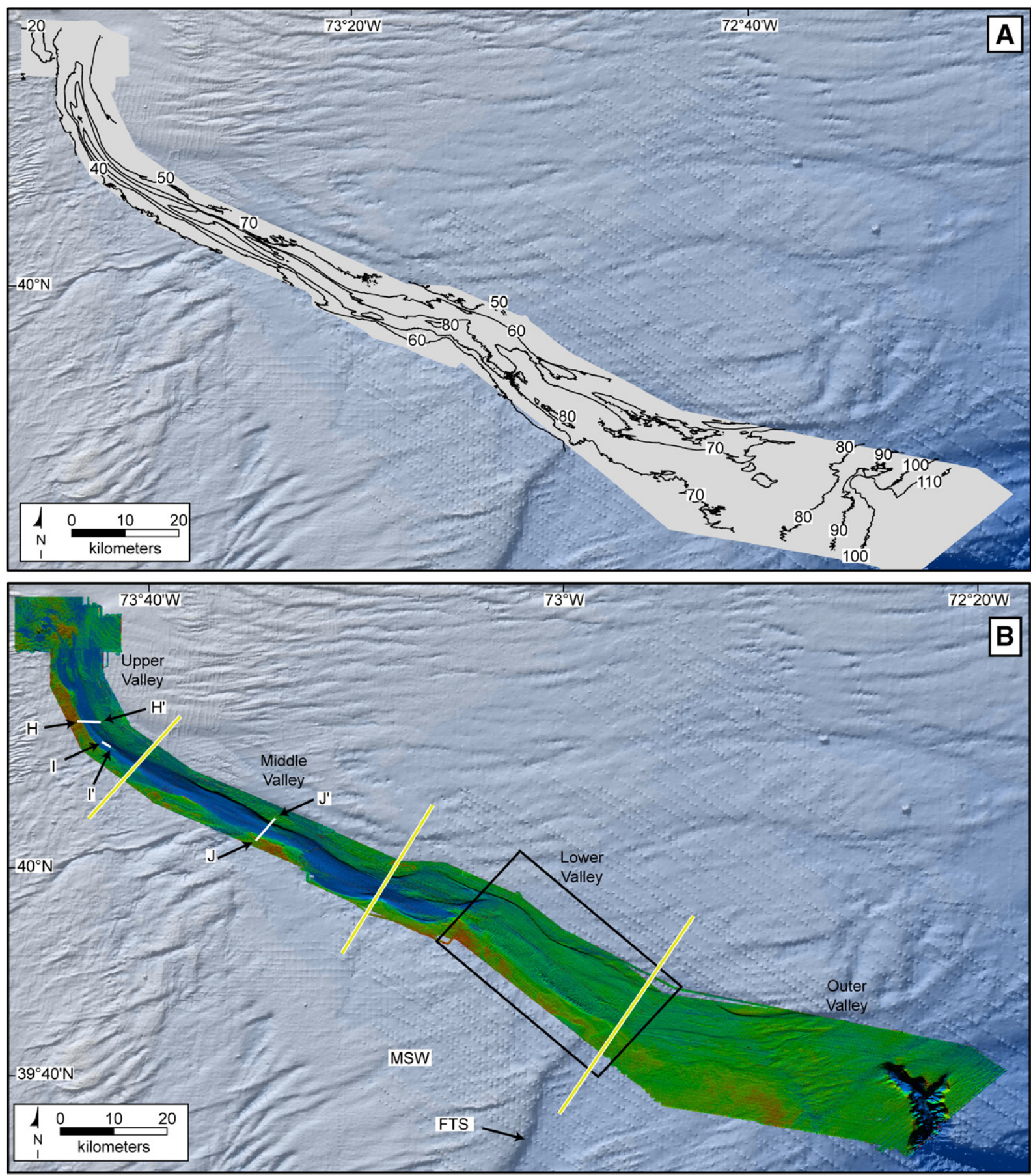

Fig. 2. Geographic divisions, water depths, and acoustic backscatter intensity from multibeam surveys in the Hudson Shelf Valley. (A) Contour map of water depths (meters). (B) Pseudo-colored, shaded relief image of multibeam bathymetry and acoustic backscatter intensity (multibeam data in area of Hudson Shelf Valley only). Low acoustic backscatter (blue tones) corresponds to fine-grained sediment (generally finer than medium sand), high acoustic backscatter (yellow/orange/red tones) corresponds to coarse sediment and rough-textured surfaces including rocky outcrops. Geographic divisions shown by yellow lines. Also shown are locations of seismic and depth profiles and enlarged area in Fig. 9 (box). Abbreviations and background bathymetry data follow Fig. 1. 


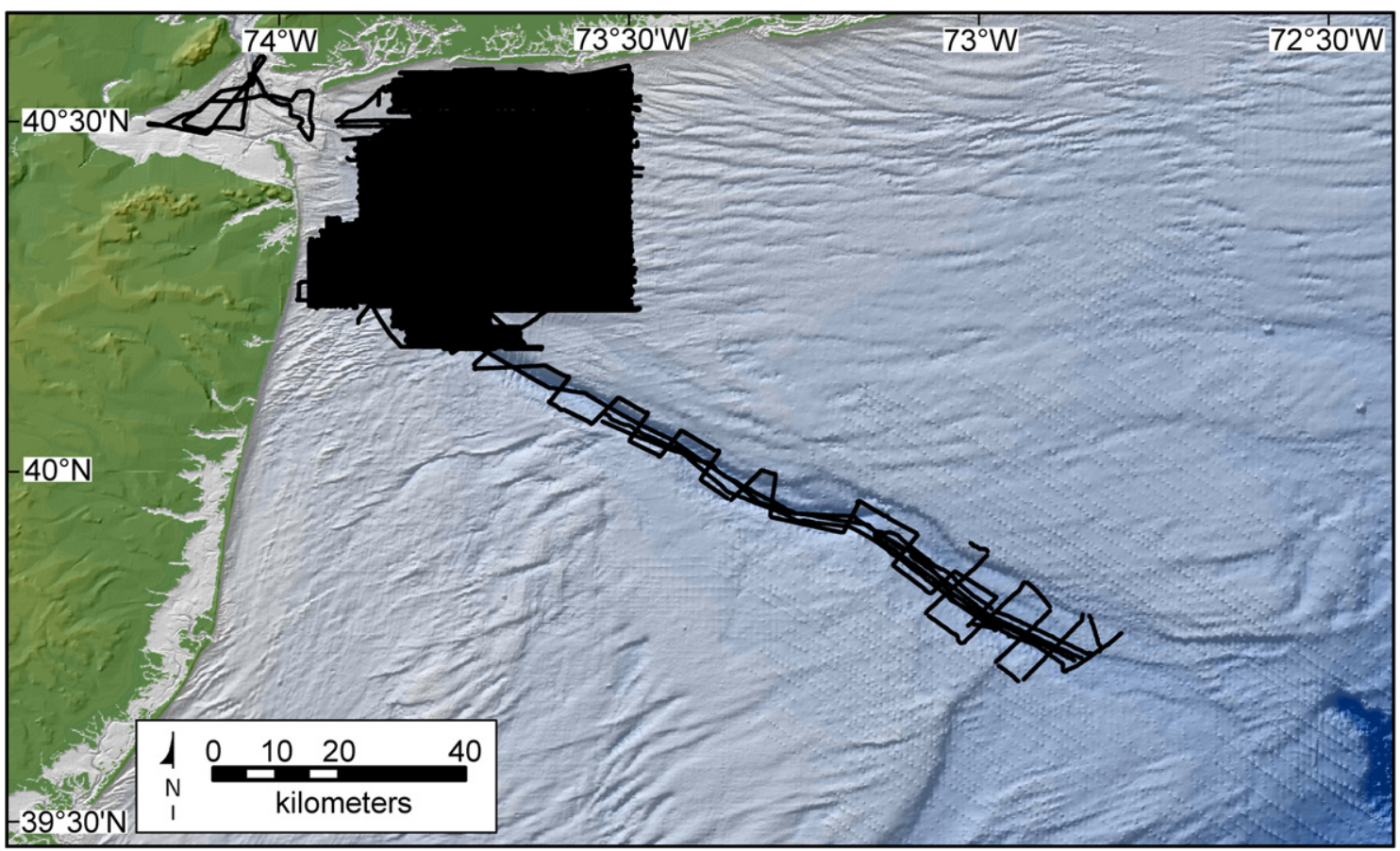

Fig. 3. Map showing tracklines of geophysical surveys in the study area. Dense coverage in the Christiansen Basin and upper Hudson Shelf Valley consists of east-west tracklines spaced $300 \mathrm{~m}$ apart.

complex fluvial/shelf system. Results yield insight into the Late Wisconsinan drainage history of glacial lakes in this region that bears on the processes that imparted the present form of the Hudson Shelf Valley. Results also provide physical evidence for episodic freshwater delivery from the Hudson River to the Atlantic Ocean.

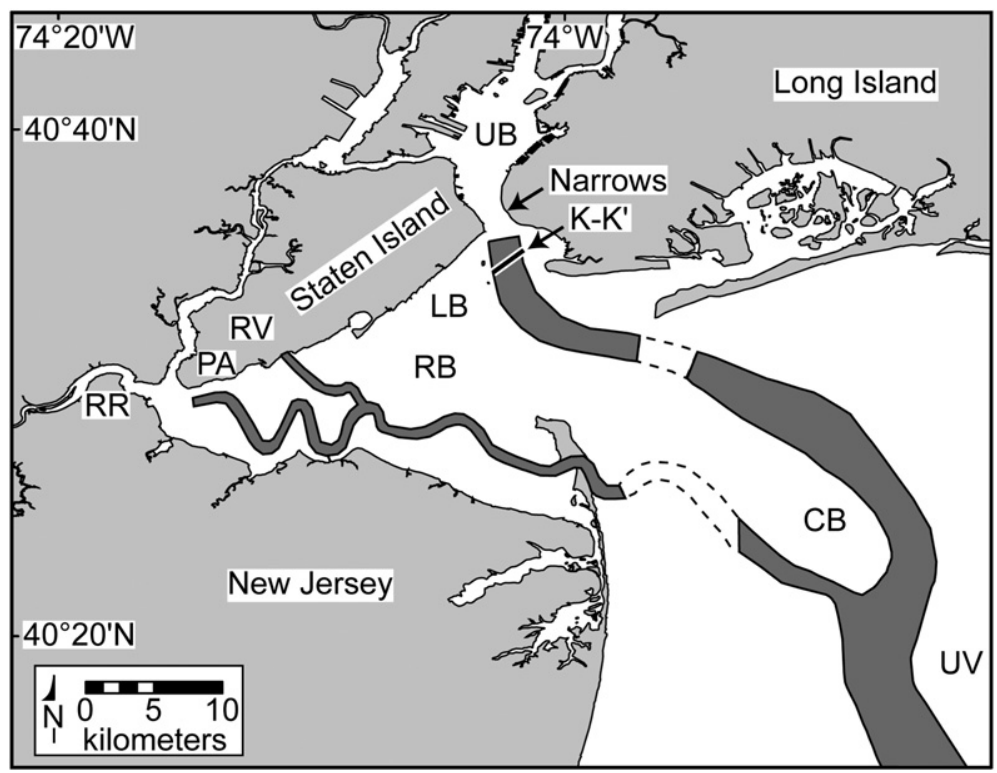

Fig. 4. Map showing the course of the paleo-Hudson River fluvial channel from the Narrows to the upper portion of the Hudson Shelf Valley, as well as paleo-channels for the Raritan River (after Gaswirth et al., 2002) and probable Richmond Valley spillway. Seismic profile along $\mathrm{K}-\mathrm{K}^{\prime}$ is shown in

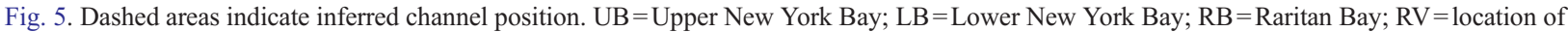
Richmond Valley spillway; PA= location of Perth Amboy spillway; RR=Raritan River; CB=Christiansen Basin; UV=Upper Hudson Shelf Valley. 


\section{Study area}

The 150-km-long Hudson Shelf Valley (HSV) is the largest physiographic feature on the mid-Atlantic continental shelf (Fig. 1). The HSV is the submerged seaward extension of the Hudson River drainage system that connects the Hudson River to the Hudson Canyon. Unlike other valleys on the mid-Atlantic shelf such as the Delaware (Swift et al., 1980) and Susquehanna (Twichell et al., 1977), however, much of the HSV has not been filled with sediment. The valley begins in a broad, shallow basin (Christiansen Basin) and extends offshore 5-40 $\mathrm{m}$ below the surrounding shelf surface to a seaward terminus at a shelf-edge delta near the head of Hudson Canyon (Ewing et al., 1963; Emery and Uchupi, 1972).

The ancestral Hudson River is generally thought to have had a long history that began in the Late Cretaceous. Uplift and tilting of the margin, resulting in landward erosion and seaward growth, continued into the Tertiary (Thompson, 1936; Soren, 1971). The Hudson River was repeatedly downcut into Cretaceous coastal-plain strata during periods of Pleistocene marine regression (Suter et al., 1949; Knebel et al., 1979). Scouring of the lower Hudson River during the last glaciation formed a fiord in the region north of New York City (Newman et al., 1969).

More recent fluvial downcutting was amplified by drainage of late Wisconsinan glacial lakes (Newman et al., 1969), culminating in the failure of the terminal moraine dam at the Narrows, which is a break in the Harbor Hill moraine (Fig. 1) between Staten Island and Long Island, New York. Borehole data across the Narrows suggest that more than $100 \mathrm{~m}$ of Pleistocene and Cretaceous sedimentary material was eroded as a result of this breaching event (Fluhr, 1962; Newman et al., 1969). Uchupi et al. (2001) proposed that deposition of sediment lobes on the continental shelf (Fig. 1) and erosion of the HSV were a consequence of this catastrophic drainage.
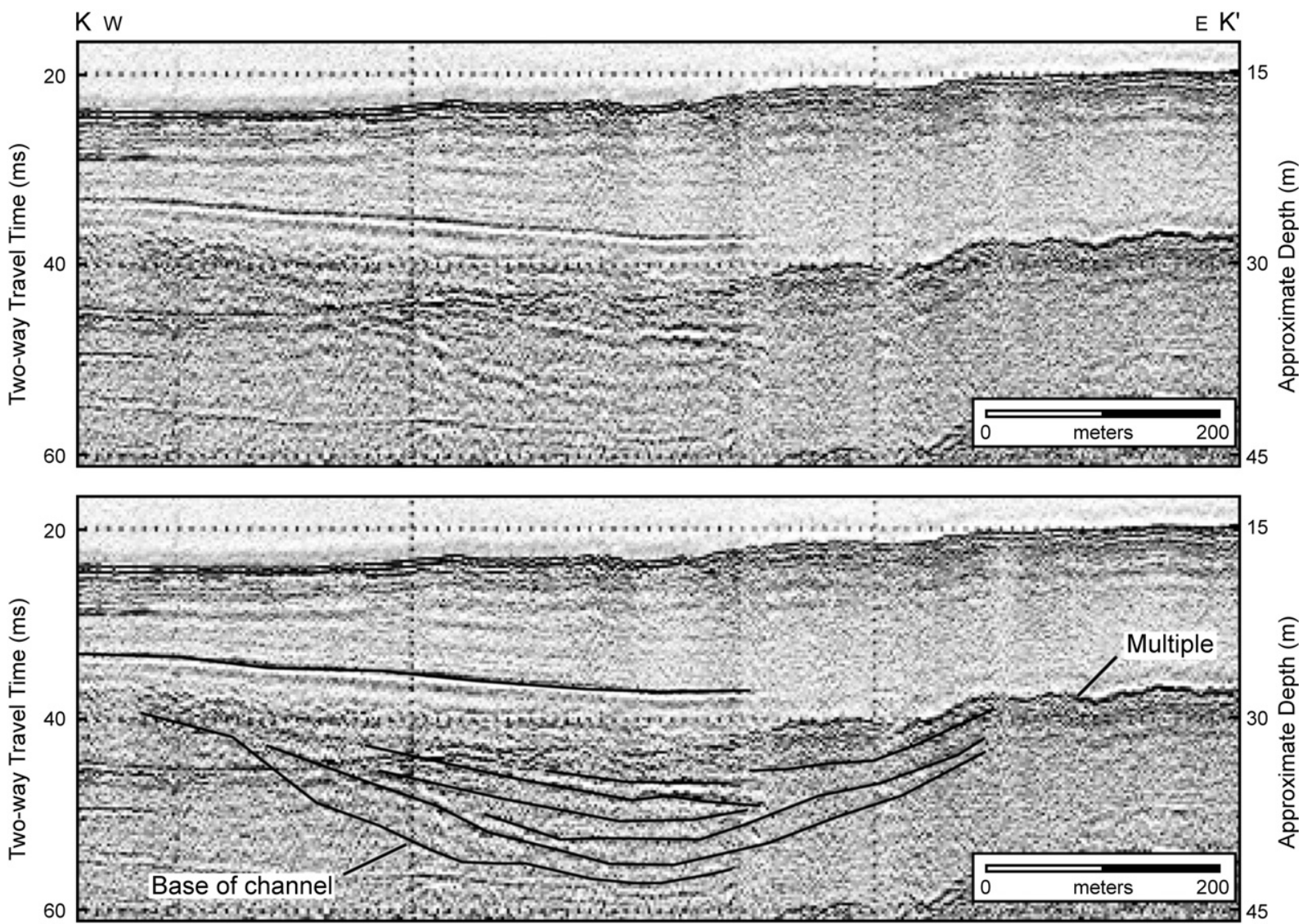

Fig. 5. Uninterpreted (upper) and interpreted (lower) seismic reflection profile (boomer) across the Hudson River adjacent to the Narrows in northern Lower New York Bay. See Fig. 4 for location. 

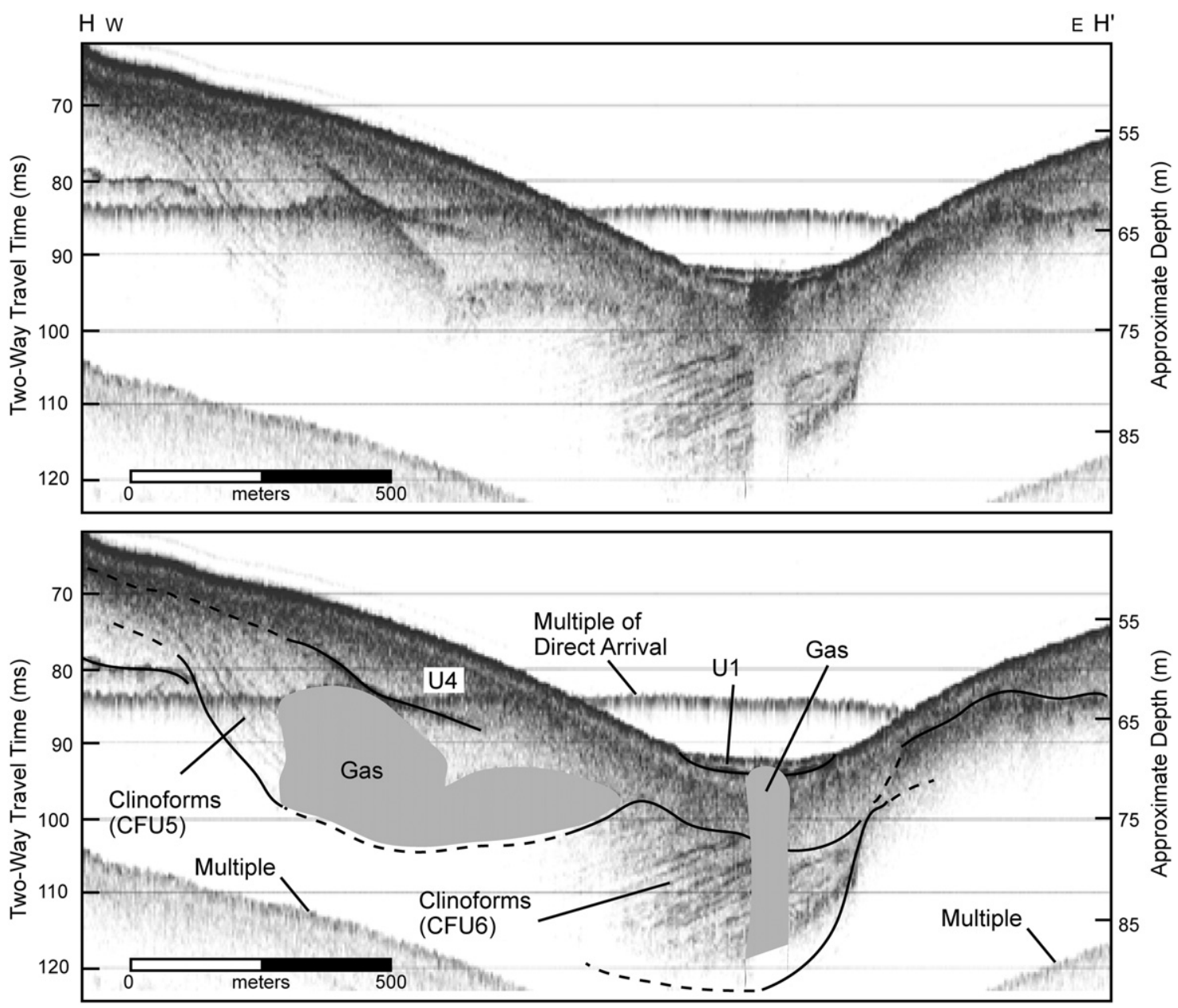

Fig. 6. Uninterpreted (upper) and interpreted (lower) seismic reflection (CHIRP) profile across the upper Hudson Shelf Valley (HSV) showing clinoforms within two of the channel-fill units (CFU5 and CFU6) that can be mapped regionally in this area. Unit U4 is mappable in the upper and middle HSV as a massive deposit capping the channel-fill units. U1 is a thin deposit of modern sewage sludge resulting from offshore disposal. Gas in CFU5 and U1 produces acoustic blanking. See Fig. 2 for location (after Schwab et al., 2003).

\subsection{Methods}

Surveys of the HSV were conducted using multibeam swath bathymetry (Butman et al., 2003) and highresolution seismic profiling systems (Schwab et al., 2003) (Figs. 2 and 3). A Simrad Subsea EM 1000 Multibeam Echo Sounder ( $95 \mathrm{kHz}$ ) was used to acquire bathymetry and backscatter intensity data. This system utilizes 60 electronically aimed beams spaced at intervals of $2.5^{\circ}$ that insonify a strip of sea floor as much as 7.5 times the water depth (swath width of 100-400 m within the survey area). The horizontal resolution of the beam on the sea floor is approximately $10 \%$ of the water depth (3-50 $\mathrm{m}$ in the survey area). Vertical resolution is approximately $1 \%$ of the water depth $(0.3-5 \mathrm{~m}$ in the survey area). The bathymetric soundings were corrected for tidal elevation and are reported relative to mean sea level.

Seismic reflection data were acquired using a Datasonics 2-7 kHz swept FM (CHIRP) subbottom profiler, and a 300- to 3000-Hz boomer subbottom profiler. The CHIRP subbottom data were acquired at a $250-\mathrm{ms}$ fire interval, 250-ms sweep, and 0.244-ms sample interval. The boomer data were acquired at a 0.5 -s fire interval, 200-ms recording interval, and a 0.062 - or 0.125 -ms sample interval. Ship position was determined using differential GPS. The CHIRP towfish was navigated relative to the ship using an acoustic-ranging system. The seismic data were logged digitally and processed with Promax seismic processing software. An automatic gain control was applied to the CHIRP data with a $10-\mathrm{ms}$ window. The boomer data were processed 

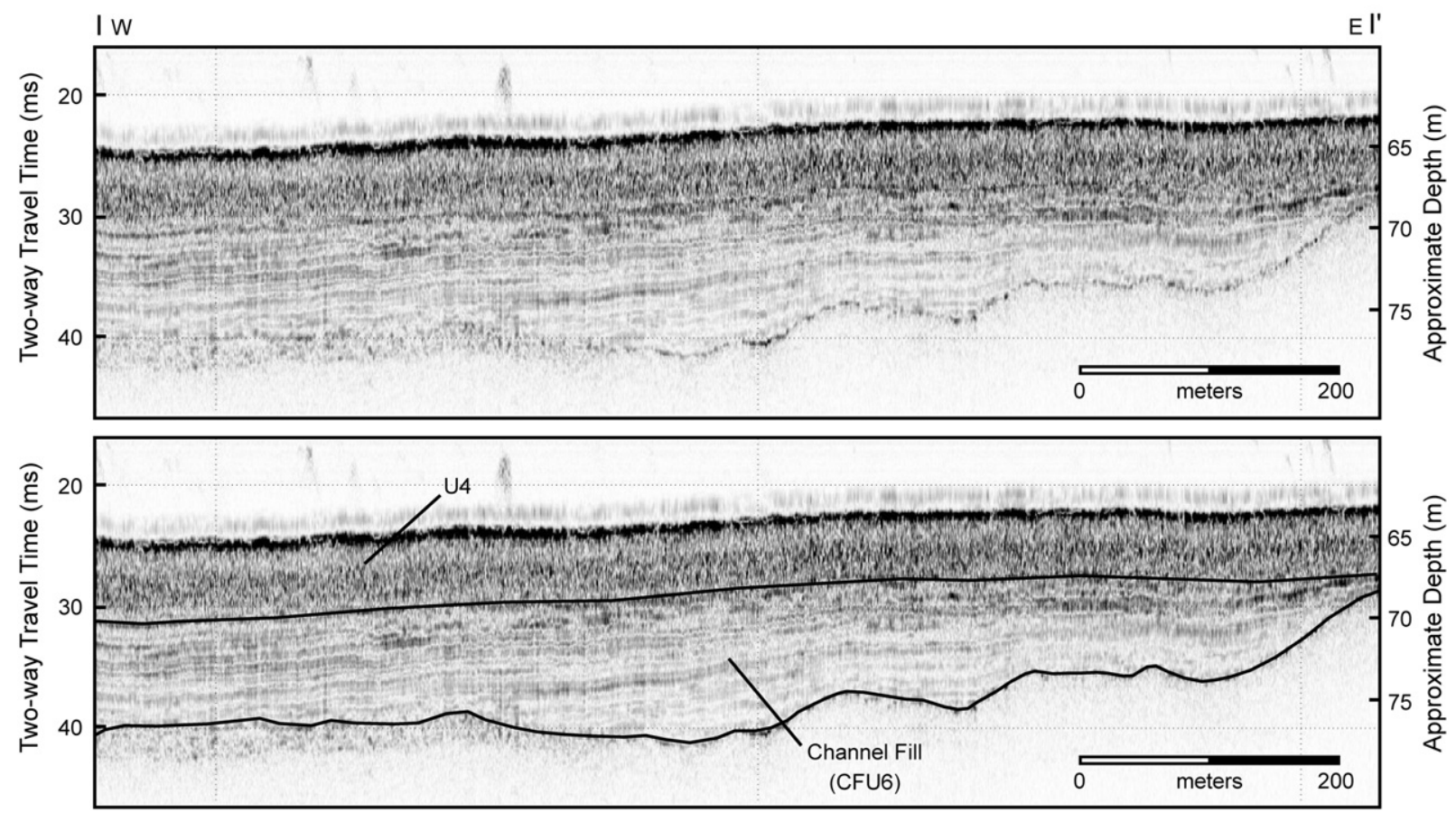

Fig. 7. Uninterpreted (upper) and interpreted (lower) seismic reflection profile (CHIRP) along the axis of the upper Hudson Shelf Valley showing CFU6 and the overlying unit U4. See Fig. 2 for location.

by applying a zero-phase Butterworth band-pass filter $(325-2400 \mathrm{~Hz})$ followed by a time-varying gain.

\section{Results}

\subsection{Seismic-stratigraphic framework}

The deepest seismic-stratigraphic unit resolved in the seismic reflection data is interpreted to be composed of Upper Cretaceous to Lower Tertiary, semi-lithified, coastal-plain strata (Williams, 1976; Schwab et al., 1997a,b; 2000, 2003). These strata are recognizable on seismic profiles as a series of conformable bedding-plane reflections with high-amplitude returns with a low angle $\left(\sim 1^{\circ}\right)$, monoclinal, southeastward dip. The coastal-plain strata crop out on the sea floor at the head of the HSV and to the west off New Jersey (Williams and Duane, 1974; Williams, 1976; Schwab et al., 1997a,b). Where buried, the coastal-plain strata are truncated by the coastal-plain unconformity, a regional angular unconformity that has been identified throughout the U.S. Atlantic margin (Poag, 1978). This unconformity separates the late Cretaceous to Tertiary coastal-plain strata from overlying Quaternary sediment (Schwab et al., 2003).

Interpretation of seismic reflection data from Lower New York Bay (south of the Narrows) to the head of the
HSV in Christiansen Basin indicates that the Hudson River channel, which is now buried, was $2-4 \mathrm{~km}$ wide in this area (Fig. 4) and had thalweg depths reaching at least $45 \mathrm{~m}$ below present sea-level, using a nominal velocity of $1500 \mathrm{~m} / \mathrm{s}$ (Fig. 5). The base of the fluvial deposits here are bounded by the coastal-plain strata. In the seismic reflection profiles, the surface of the coastalplain strata is characterized by abundant diffractions, indicative of a very rough surface, with small-scale

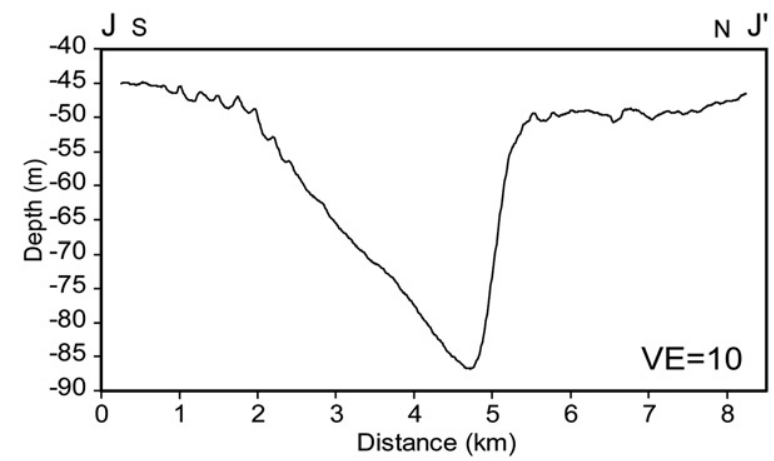

Fig. 8. Bathymetric profile across the upper Hudson Shelf Valley. The valley is more than $3 \mathrm{~km}$ wide at this location, as much as $35 \mathrm{~m}$ deep relative to the surrounding continental shelf, and is asymmetric with a steeper northern flank. See Fig. 2 for location. 
relief of 1-2 m. There are also two prominent channels cut into the seafloor of Raritan Bay (Fig. 4). The largest is the meandering valley of the paleo-Raritan River (Gaswirth et al., 2002). At least one other channel appears to originate on Staten Island, at the base of the Harbor Hill terminal moraine. The quality of the seismic profiles in Lower New York Bay and Raritan Bay is strongly affected by the presence of gas in the sedi- ments, as well as human activities such as dredging and dumping that have taken place over the past few hundred years. Thus, details of the internal stratigraphy of the fluvial deposits are not well resolved because they are obscured by gas, have been physically removed by dredging, or have been covered by dumped material that either traps gas or otherwise attenuates the seismic signal.

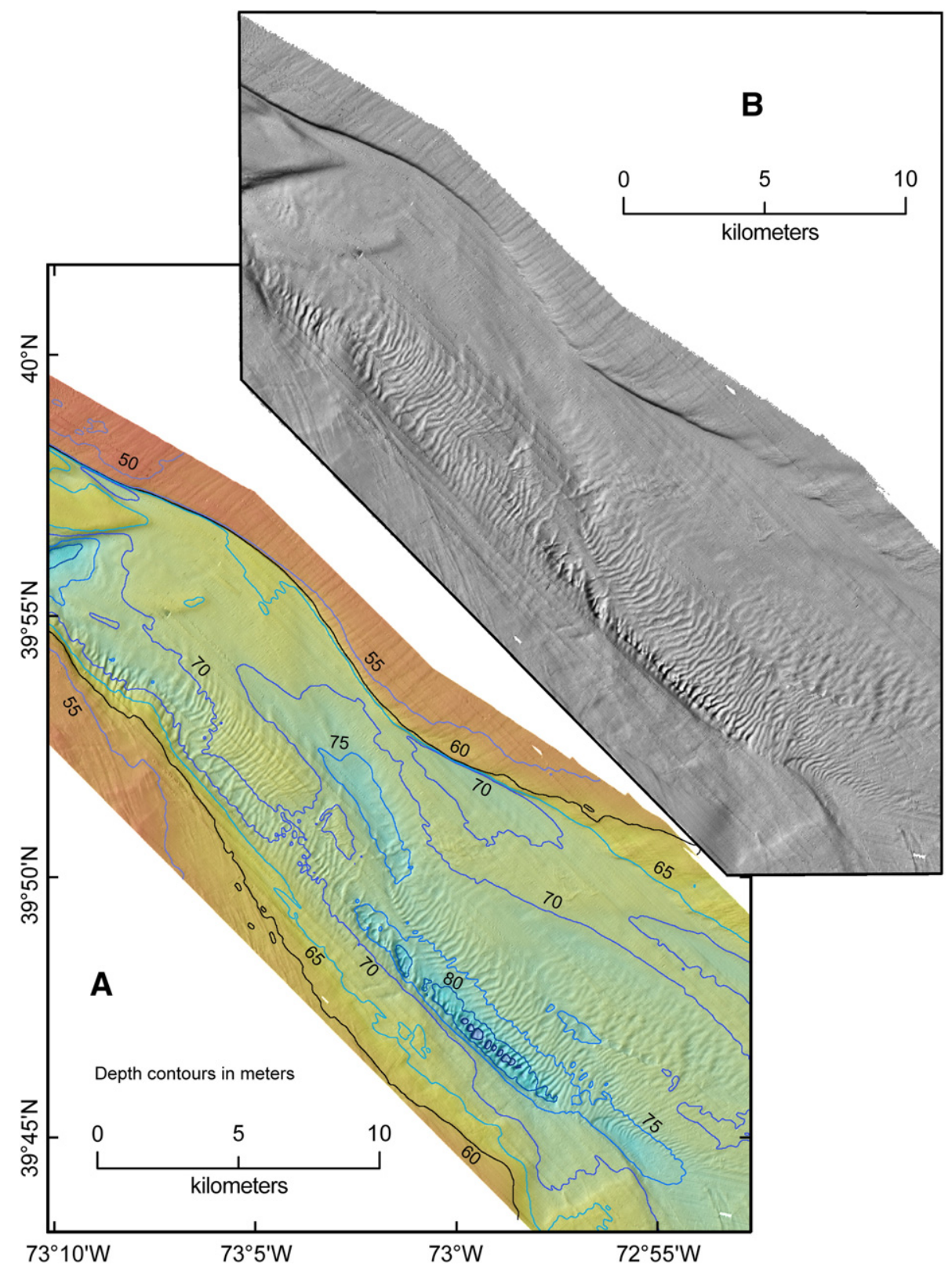

Fig. 9. Shaded relief image of multibeam bathymetry of a portion of the lower Hudson Shelf Valley. The image was created by exaggerating the bathymetry $20 x$, and illuminating from $315^{\circ}$ at an elevation of $45^{\circ}$. See Fig. 2 for location. The straight along-valley lines are artifacts in the multibeam data. (A) Large bedforms dominate the surface of this part of the valley. Note the steep northeastern edge of the valley. The deepest bedforms are along the southwestern-most side of the valley enclosed by the $80-\mathrm{m}$ isobath. (B) Grayscale shaded relief image of this area. 

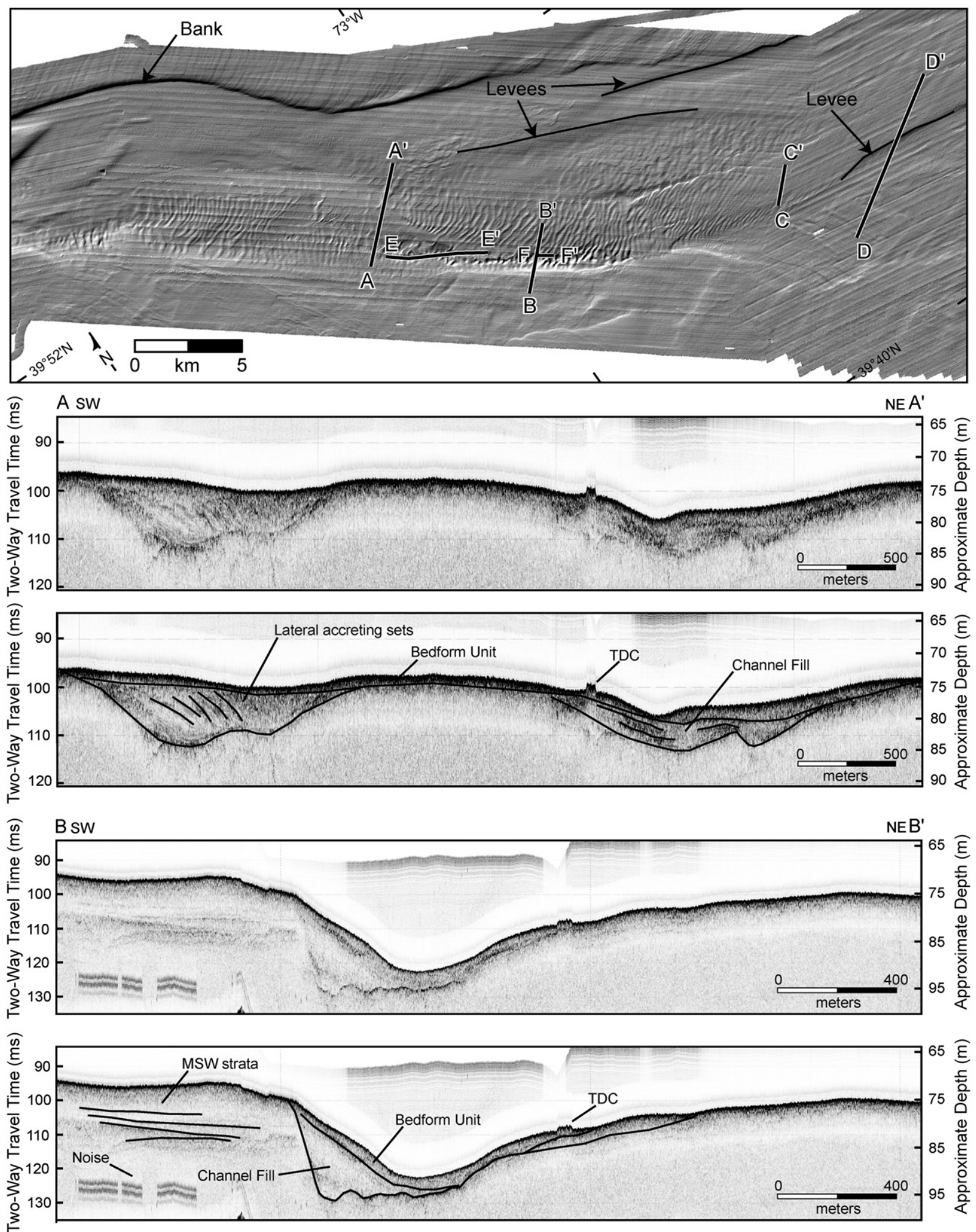

Fig. 10. Map showing locations of seismic profiles in the lower Hudson Shelf Valley, along with uninterpreted (upper) and interpreted (lower) seismic reflection profiles (CHIRP). Additional seismic profiles are shown in Fig. 11. See text for discussion. TDC=artifact due to CHIRP towfish depth change. 


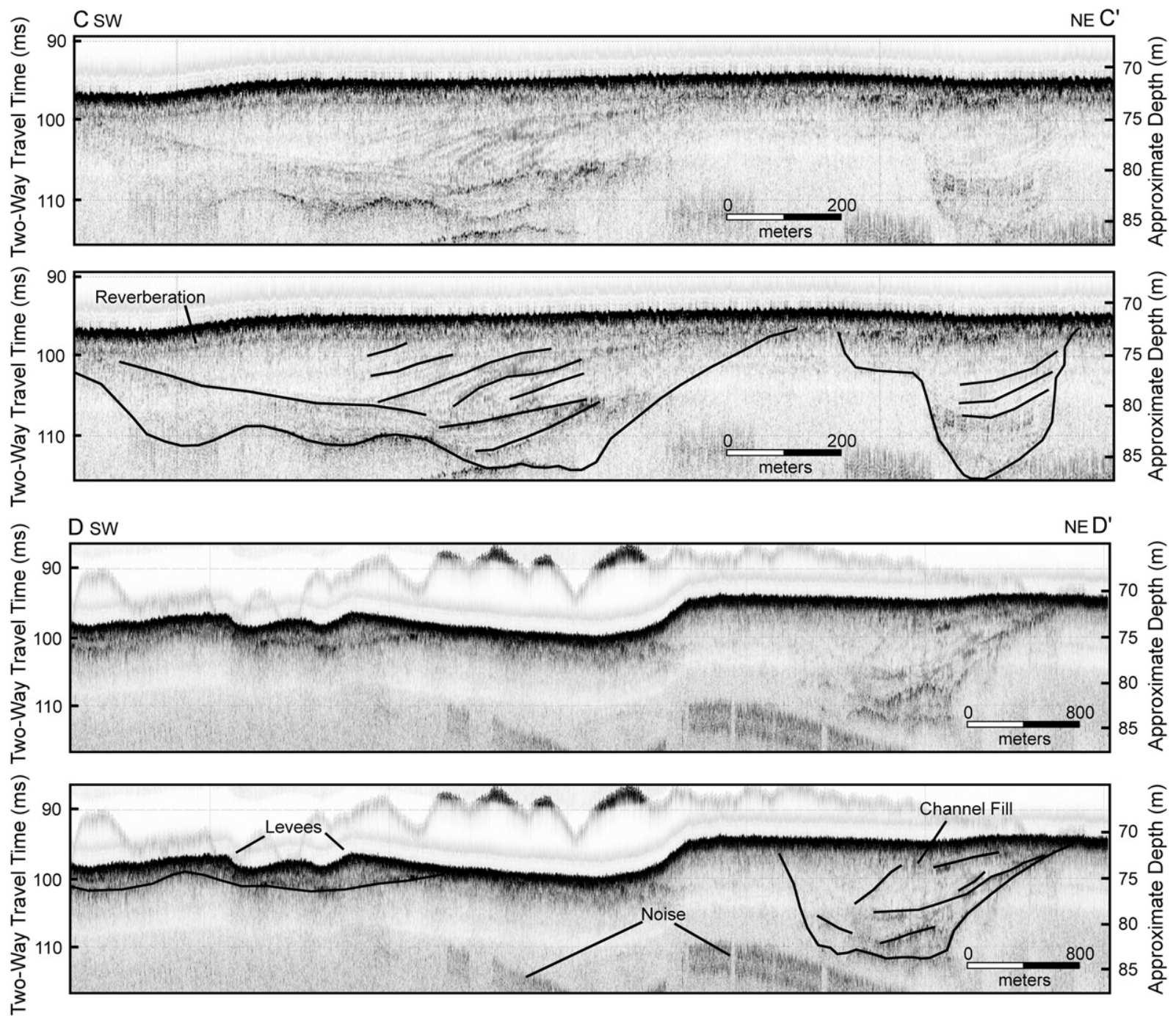

Fig. 10 (continued).

At the head of the HSV, seismic profiles show at least three (possibly four) cut-and-fill sequences filling the base of the valley (two are illustrated in Fig. 6). These sequences suggest several episodes of channel cutting followed by partial channel filling. The sequences can be mapped as distinct channel-fill units (CFUs), informally designated as CFU5, CFU6, and CFU7 with increasing depth in section (Schwab et al., 2003). An acoustically amorphous unit as much as $5 \mathrm{~m}$ thick (unit U4; Schwab et al., 2003) unconformably overlies the channel-fill units (Figs. 6 and 7). This unit is present throughout the upper and middle HSV.

In the distal portion of the HSV, the seismic lines are less dense (Fig. 3), and individual channel fill units described above cannot be correlated across the region.
These data show that the fluvial channels generally overlap each other and follow the course of the HSV to within $40 \mathrm{~km}$ of the head of Hudson Canyon where they bifurcate on the low-gradient outer shelf (Fig. 2).

\subsection{Bathymetry}

Based on topography derived from multibeam bathymetric soundings (Butman et al., 2003), the HSV can be divided into upper, middle, lower and outer sections (see Fig. 2). The upper valley begins at about $30 \mathrm{~m}$ water depth in the Christiansen Basin and terminates at about $65 \mathrm{~m}$ water depth at the beginning of a series of semienclosed basins in the valley axis. This upper part of the valley is $25 \mathrm{~km}$ long, trends almost north-south, and the 

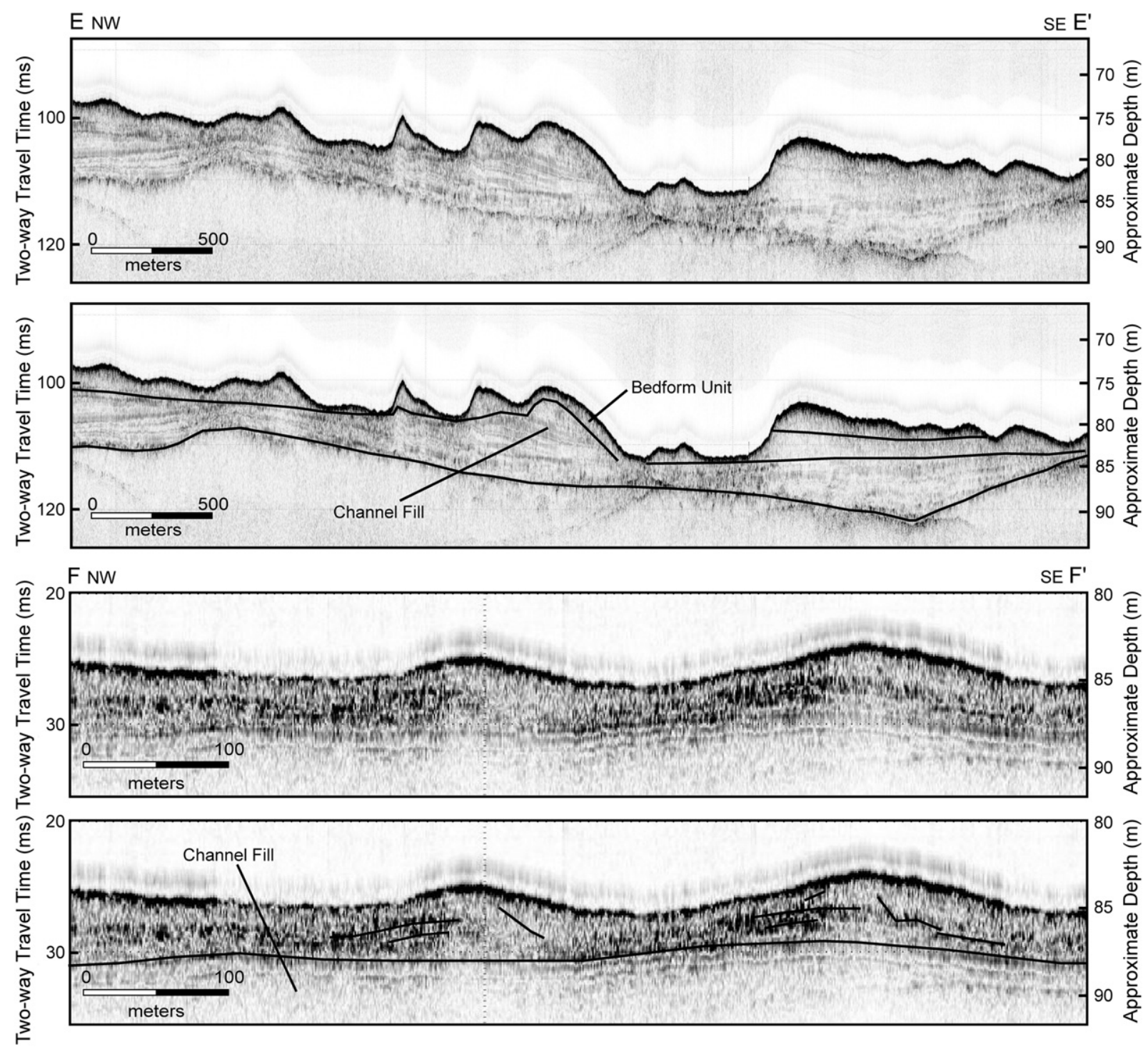

Fig. 11. Uninterpreted (upper) and interpreted (lower) seismic reflection profiles (CHIRP) along the axis of the lower Hudson Shelf Valley showing the different types of bedforms present on the seafloor and beneath the surface. Profile locations shown in Fig. 10. See text for discussion.

water depth deepens nearly linearly with an axial slope of about $0.08^{\circ}$.

The middle valley begins at about $65 \mathrm{~m}$ water depth and ends at nearly the same depth. At the beginning of the middle valley the orientation of the axis changes from southward to southeastward. The middle valley is about $5 \mathrm{~km}$ wide and is $20-40 \mathrm{~m}$ deeper than the adjacent shelf. The most prominent feature of the middle valley is its well-defined, linear northeastern edge (Fig. 8) with up to $30 \mathrm{~m}$ of relief locally and which extends for nearly $30 \mathrm{~km}$ along the valley (Fig. 2).

The lower valley starts in 65-70 m water depth and ends in 75-80 $\mathrm{m}$ water depth where it cuts through the seaward edge (Fortune/Tiger shore) of the mid-shelf wedge (Fig. 2). The lower valley is $10 \mathrm{~km}$ or more wide and has a poorly defined axis that is $15-25 \mathrm{~m}$ deeper than the adjacent shelf. A relatively steep slope $\left(10-20^{\circ}\right)$ with up to $15 \mathrm{~m}$ of relief runs along the northeastern side of the lower valley (Fig. 9). An elongate field of large bedforms covers an area approximately $30 \mathrm{~km}$ long and $4 \mathrm{~km}$ wide along the southwestern side of the valley (Fig. 9). A series of semi-circular depressions 4-5 m deep and a few hundred meters across are contained in a basin enclosed by the 76-m isobath along the southwestern edge of the bedform field; the deepest water depth $(89 \mathrm{~m})$ in the lower valley occurs in these depressions. 


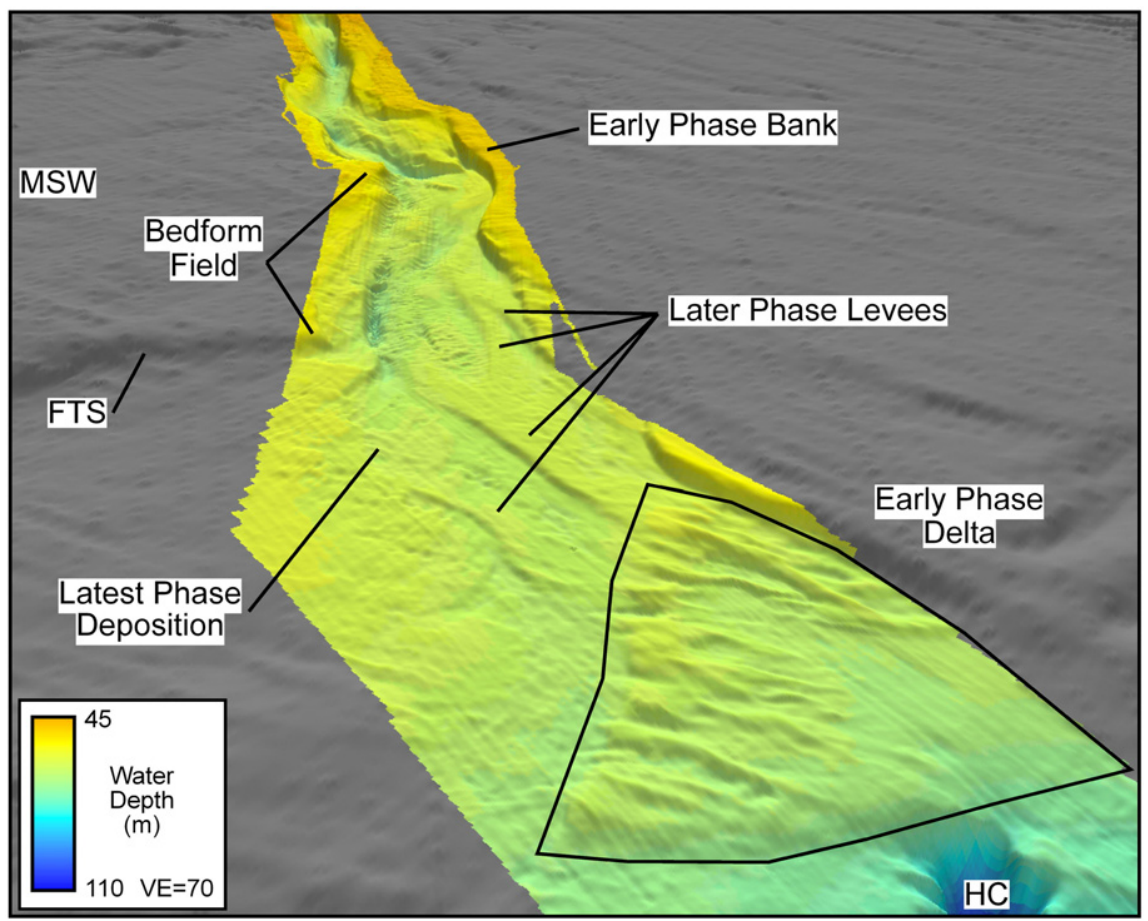

Fig. 12. Perspective view of shaded-relief multibeam bathymetry, colored by water depth, looking to the northwest from just south of the head of Hudson Canyon. The area outside of the multibeam data shows shaded relief using the NOAA Coastal Relief Model. The faint along-valley striping is an artifact in the multibeam data. MSW=Mid-Shelf Wedge; FTS=Fortune/Tiger Shore; HC=Hudson Canyon.

The outer valley extends eastward from the lower valley and ends at the head of the Hudson Canyon. A series of elongate topographic highs trending eastnortheast separate the outer valley from the head of Hudson Canyon (Figs. 2 and 3). The ridges define a roughly triangular area, $\sim 20 \mathrm{~km}$ on a side, just landward of the canyon head. The crests of these topographic highs are $8-10 \mathrm{~m}$ above the adjacent seafloor.

\subsection{Bedform field}

A prominent feature of the lower HSV is an elongate field of large bedforms about $30 \mathrm{~km}$ long and $4 \mathrm{~km}$ wide (Fig. 9). The bedforms have a height of 3-6 $\mathrm{m}$ and wavelength of $150-300 \mathrm{~m}$, with crests oriented orthogonal to the valley axis. Individual bedform crests can be traced up to $3 \mathrm{~km}$ across the valley. The bedforms may be either asymmetrical or symmetrical in crosssection. In plan view, they have a 2-D to 3-D dune morphology (Ashley, 1990). The bedforms appear to be confined within low levees (Fig. 10) and do not extend across the entire width of the valley.

High-resolution CHIRP subbottom data from the bedform field (Figs. 10 and 11) indicate that the bedforms are part of a discrete sedimentary unit that uncon- formably overlies the channel-fill units in the lower valley (Fig. 10, A-A', B-B', $\mathrm{C}-\mathrm{C}^{\prime}$ ). Bedforms also extend farther across the valley than any individual channel-fill unit. The bedforms unit averages $2-3 \mathrm{~m}$ thick, with maximum thicknesses less than $5 \mathrm{~m}$. At the seaward terminus of the bedform field, the unit thins (Fig. 10, C-C $\mathrm{C}^{\prime}$ ) and is not resolved in the seismic data. Levees bounding the bedforms can be traced down the valley, where the unit containing the bedforms thickens again and levees bounding a shallow topographic channel are visible (Fig. 10, D-D').

In seismic cross-sections, bedforms have two distinct morphologies and internal structures (Fig. 11). The topographic low along the southern side of the valley is a location where channel-fill occurs in the shallow sub-surface. In this region, the bedforms are often asymmetric with the steeper side facing up-valley (Fig. 11, E-E'). The bedforms have a depositional upper layer that is up to a meter thick, but they have a core that is composed of the underlying channel-fill unit (Fig. 11, E-E'). Thus, it appears that the bedforms on the southwestern-most side of the valley were initially erosional in nature; troughs were likely formed by scour into the underlying channel-fill. In places, erosional downcutting appears to have removed nearly $5 \mathrm{~m}$ 
of sediment. Above the scour surface, the bedforms become depositional.

Outside of the topographic low, the bedforms are nearly symmetrical and have visible internal reflections (Fig. 11, $\mathrm{F}-\mathrm{F}^{\prime}$ ). The lowermost reflections generally follow what appears to be a wavy erosional surface. Upper reflections dip up-valley on the up-valley side of the bedform. These internal structures suggest that the bedforms may be antidunes (Allen, 1982; Alexander et al., 2001).

\section{Discussion}

Geophysical data presented in this paper provide new insight into the processes that formed the present Hudson Shelf Valley. The HSV is interpreted to have been carved initially by precipitation and meltwater runoff during the Wisconsin glaciation, along with drainage of early glacial lakes. A later flood resulting from the failure of the Harbor Hill terminal moraine dam at the Narrows between Staten Island and Long Island allowed glacial Lake Hudson (the lake initially impounded by the Harbor Hill moraine) to drain across the continental shelf through the existing valley. Available data on the timing of the drainage of Lake Hudson and other lakes constrain the timing of the flood event.

\subsection{Glacial drainage and timing of the meltwater flood}

The initial formation of the present HSV was likely due to fluvial incision during the advance of the LIS to its terminal position. Variations in precipitation, runoff from the ice sheet, and diversion of rivers (e.g., the Raritan River; Stanford, 1993) by the advancing ice probably contributed to multiple channel cut-and-fill complexes (CFUs 5-7) imaged beneath and adjacent to the HSV along its length (Figs. 6 and 10). The fluvial systems mapped in the HSV may also represent retrenchment in the position of an older channel, but because the mapped channels are eroded into Cretaceous sediments (Schwab et al., 2003), any earlier stratigraphic record has been removed.

Once the ice sheet began retreating from its maximum Wisconsinan position, early glacial lakes Bayonne and Hackensack drained through spillways in the terminal moraine at Perth Amboy and Richmond Valley (Stanford and Harper, 1991). Channels at the bases of these spillways exist in lower New York and Raritan Bays (Fig. 4) and extend eastward to the head of the HSV. As the ice continued its northward retreat, Hell Gate in the East River was deglaciated, which initiated Hudson River basin drainage into the Long Island Sound lowlands (Lake Connecticut) and also provided a secondary outlet for
Lake Hackensack (Stanford and Harper, 1991). Subsequent drainage of lakes in the Hudson River basin (Lakes Hudson, Albany and Vermont), as well as Lake Iroquois drainage through the Mohawk Valley outlet between the Lake Ontario basin and the Hudson River valley (Muller and Prest, 1985; Pair and Rodrigues, 1993), were also routed through Hell Gate. According to Ridge (1997), this routing persisted until after $12,000{ }^{14} \mathrm{C}$ year BP. This drainage routing is probably responsible for the formation of Block Channel on the continental shelf southeast of Long Island (Fig. 1; Uchupi et al., 2001).

Reconstructed drainage routing history (Stanford and Harper, 1991) suggests that no meltwater exited the Hudson River southward across the New York-New Jersey shelf until the breach at the Narrows took place. Weiss (1974) reported that the onset of marine conditions north of the Narrows occurred by $10,280 \pm 270{ }^{14} \mathrm{C}$ year BP $(11,465-11,422,12,386-11,558,12,620-12,474$ cal BP). More recently, Donnelly et al. (2005) found that estuarine silt overlying glacial lake sediments in the lower Hudson River has an age of $10,350 \pm 65{ }^{14} \mathrm{C}$ year BP (12,035-11,959, 12,354-12,083, 12,598-12,502 cal BP). Thus, dam failure at the Narrows and associated flood event must have occurred between $\sim 12,000-$ $10,300{ }^{14} \mathrm{C}$ year BP. Water level changes in the Hudson basin associated with the drainage routing of glacial lakes Iroquois, Vermont, and Albany between 11,300 and $10,900{ }^{14} \mathrm{C}$ year BP (Licciardi et al., 1999; Clark et al., 2001; Rayburn et al., 2005) may have precipitated dam failure at the Narrows. The most likely time interval for breaching of the moraine dam at the Narrows is between $12,300{ }^{14} \mathrm{C}$ year BP (Ridge, 1997; Licciardi et al., 1999) and the initiation of the Champlain Sea at about $11,100{ }^{14} \mathrm{C}$ year BP (Rodrigues, 1988; Ridge et al., 1999; Richard and Occhietti, 2005). Recently, Donnelly et al. (2005) suggested an age of $\sim 11,450{ }^{14} \mathrm{C}$ year BP $(\sim 13,350$ cal BP) for the flood event.

Dam failure at the Narrows is inferred to have been catastrophic for several reasons: (1) reconstructed water planes of Lakes Hudson and Albany project to the terminal moraine at least $21 \mathrm{~m}$ below its crest (Stanford and Harper, 1991); (2) borehole data at the Narrows suggest that more than $100 \mathrm{~m}$ of Pleistocene and Cretaceous sediments, along with most of the previously deposited lacustrine sediment, was eroded as a result of this breaching event (Fluhr, 1962; Newman et al., 1969); and (3) as described above, the Hudson channelfill immediately downstream from the Narrows is characterized by a rough basal surface and a massive, poorly defined internal structure. These observations are consistent with intense erosion followed by rapid emplacement of sediment, supporting a swift rise in water level 
in Lake Hudson that overtopped the moraine and caused catastrophic dam failure.

\subsection{Shelf valley and bedform formation}

The early, outburst-flood phase of the flood event immediately following dam failure at the Narrows was probably characterized by a high-volume, non-cohesive sediment gravity flow (Middleton and Hampton, 1976) down the HSV and across the outer continental shelf. This event may be responsible for the formation of sediment lobes on the mid-shelf (Uchupi et al., 2001; Donnelly et al., 2005). The roughly triangular area of topographic ridges near the head of the Hudson Canyon (see Figs. 2 and 12) may be a subaqueous delta also resulting from this early phase. Later phases of the flood event presumably eroded this deposit into its present ridged form.

Deposition of the sediment gravity flow was probably followed by a water-flood phase caused by continued lake drainage, during which we infer that the large bedforms developed within the lower valley. Levees within the lower and outer valley clearly suggest several phases of flow. The later phases appear to have migrated progressively southward, as suggested by the series of levees. Down-valley from the bedform field, and contained within the same levee system, deposits form a veneer on the outer valley surface, which in turn are cut by a shallow topographic channel with bounding levees (Fig. 10, D-D'). The morphology of the lower HSV (Fig. 12) is thus characterized by banks and levees, rather than a braided and anastomosed morphology as suggested by Uchupi et al. (2001).

If the surficial bedforms in the lower valley are antidunes, this suggests supercritical flows (Froude number $\geq 1$ ) during one or more flood events; the bedforms would have formed in the presence of a free water surface that was characterized by wave breaking (hydraulic jumps) (Allen, 1982; Alexander et al., 2001). The asymmetric bedforms cored by channel-fill deposits appear to be predominantly erosional in nature. They are inferred to have formed by erosion of the bedform trough into the underlying channel-fill deposits. The bedform asymmetry may be attributed to increased resistance of the channel-fill to erosion (Reineck and Singh, 1980). The erosive nature, combined with the variability in bedform height and wavelength within the topographic low, is also suggestive of a "chutes and pools" morphology (Figs. 9 and 11, E-E') that is characteristic of supercritical flows (Allen, 1982).

The form and internal stratigraphy of the bedforms is consistent with that observed in laboratory studies of supercritical flows (Middleton, 1965; Alexander et al., 2001). Kennedy (1963) found that the minimum wavelength $(L)$ of antidunes is related to flow velocity as

$L=2 \pi U^{2} / g$

where $U$ is the flow velocity and $g$ is the acceleration due to gravity. The bedforms in the lower HSV have a minimum wavelength of $150 \mathrm{~m}$, which indicates flow velocities of about $15 \mathrm{~m} \mathrm{~s}^{-1}$.

Important questions in resolving the environmental setting of the bedform field as well as the inferred outer shelf delta are the water depth and whether these features formed in a marine, estuarine, or fluvial environment. Using an approximation by Allen (1968) with Froude numbers $(\sim 1-2)$ in the range where antidunes exist yields paleo-flow depths of $\sim 5-20$ meters. The bedforms are located in present water depths of approximately $75-85 \mathrm{~m}$ within levees at depths of about $70 \mathrm{~m}$. If the flood event inferred to have created the bedforms occurred at $\sim 11,450{ }^{14} \mathrm{C}$ year BP $(\sim 13,350$ cal BP) (Donnelly et al., 2005), regional and global sea-level data (Milliman and Emery, 1968; Dillon and Oldale, 1978; Fairbanks, 1989) suggest that sea-level stood at about $75 \mathrm{~m}$ below present at that time. The transition from fluvial-dominated erosional morphology (bedforms, steep banks) in the lower valley to subaqueous marine depositional morphology (delta) in the outer valley also occurs at about $75 \mathrm{~m}$. Our paleo-environmental interpretation is that the flood event probably discharged into an estuarine and shallow marine system that formed as sea-level rose and inundated the lower HSV.

A significant aspect of the bedforms and associated morphologies in the lower valley is their apparently pristine preservation. The morphology of the bedforms, for example, does not appear to have been altered by later reworking. Similarly, the steep northeastern bank of the lower valley has not been degraded. This excellent preservation is attributed in part to their initial formation in a water depth of $\sim 10-15 \mathrm{~m}$, and in part to rapid sequestration below the depth of active marine (wave) reworking by the rapid global sea-level rise characteristic of the late Pleistocene (Fairbanks, 1989; Bard et al., 1996; Liu et al., 2004). This period of rapid sea-level rise effectively drowned the bedforms before they could be extensively reworked or destroyed.

The acoustically amorphous unit U4 (Figs. 6 and 7) is widespread throughout the upper and middle HSV, covering an area of about $250 \mathrm{~km}^{2}$. This $\sim 5$-m-thick unit thins in the distal portion of the lower valley and terminates just up-valley from the bedform field. The massive internal character suggests rapid emplacement. 
It is possible that unit U4 represents a post-flood debris flow, but there are presently no data to confirm this speculation.

\subsection{Freshwater flux and possible climatic response}

Recent estimates of the volume of catastrophic glacial lake drainage (Rayburn et al., 2005; Donnelly et al., 2005) in the glacial lake Iroquois, Vermont, and Albany system can be used to assess the potential flux of freshwater down the Hudson River during the flood event. Rayburn et al. (2005) suggest a total discharge of $3200 \pm 480 \mathrm{~km}^{3}$ during three nearly contemporaneous events: (a) Lake Iroquois' drop from the Main to the Frontenac level $\left(570 \pm 85 \mathrm{~km}^{3}\right.$ discharged through the Mohawk outlet); (b) Lake Vermont's drop from the Coveville to the Upper Fort Ann level $\left(130 \pm 20 \mathrm{~km}^{3}\right.$ discharged through the Fort Ann outlet); and (c) the Lake Iroquois/Vermont drop from the Upper Fort Ann to the Lower Fort Ann level $\left(2500 \pm 375 \mathrm{~km}^{3}\right.$ discharged through the Fort Ann outlet). Using the volume estimates given above and the cross-sectional area of the HSV in the bedform field, the freshwater flux during the flood event is estimated to be $\sim 0.46 \mathrm{~Sv}$ for a duration of $\sim 80$ days. This flux exceeds the threshold suggested by modeling studies (Ganopolski and Rahmstorf, 2001) to have an effect on thermohaline circulation. This is a maximum estimate, however, that assumes the entire $3200 \mathrm{~km}^{3}$ of fresh water passed across the bedform field, which was probably not the case (Uchupi et al., 2001; Donnelly et al., 2005).

Using existing and new data from the Hudson River basin, Donnelly et al. (2005) were able to constrain the timing of this flood event to $11,450{ }^{14} \mathrm{C}$ year BP $(\sim 13,350$ cal BP). They suggest that this release of meltwater may have triggered the Intra-Allerød Cold Period (IACP) by inhibiting thermohaline circulation. The data from the HSV presented in this paper indicate that there is physical evidence of this addition of freshwater to the western North Atlantic.

\section{Conclusions}

The present Hudson Shelf Valley (HSV) was likely carved initially by fluvial processes during the advance of the Laurentide Ice Sheet, and subsequently by drainage of early glacial lakes in the Lake Ontario and Hudson River basins. The catastrophic failure of the terminal moraine at the Narrows (between Staten and Long Islands, New York) allowed post-Last Glacial Maximum glacial lakes to drain across the continental shelf. This flood event imparted to the Valley its modern form, including banks, levees, and a large field of subaqueous bedforms.
The timing of the flood event can be constrained between 12,000 and $10,300{ }^{14} \mathrm{C}$ year $\mathrm{BP}$, corresponding to a series of catastrophic floods and lake-level changes in upstream lakes Iroquois, Albany, and Vermont that affected freshwater flux down the Hudson River. Available data on the specific timing of the flood event suggest an age of $\sim 11,450{ }^{14} \mathrm{C}$ year $\mathrm{BP}(\sim 13,350 \mathrm{cal}$ $\mathrm{BP})$. The freshwater flux during the flood event may have been a trigger for the Intra-Allerød Cold Period.

\section{Acknowledgments}

Multibeam bathymetry surveys were conducted in cooperation with the Canadian Hydrographic Survey using the research vessel Frederick G. Creed. Bill Danforth, Jane Denny, Dave Foster, Linda Lotto, and Tammie Middleton processed the multibeam and seismic data. Caroline Roberts drafted the figures. We thank Steve Colman, Dave Twichell, David Mosher, and Bill Ryan for reviewing a draft of this paper. Contribution 11351 of the Woods Hole Oceanographic Institution. Support for N. Driscoll was provided by the Office of Naval Research and the National Science Foundation.

\section{References}

Alexander, J., Bridge, J.S., Cheel, R.J., Leclair, S.F., 2001. Bedforms and associated sedimentary structures formed under supercritical water flows over aggrading sand beds. Sedimentology 48, 133-152.

Allen, J.R.L., 1968. The nature and origin of bedform hierarchies. Sedimentology 10, 161-182.

Allen, J.R.L., 1982. Sedimentary Structures: Their Character and Physical Basis. Elsevier, Amsterdam.

Alley, R.B., Mayewski, P.A., Sowers, T., Stuiver, M., Taylor, K.C., Clark, P.U., 1997. Holocene climatic instability: a prominent, widespread event $8200 \mathrm{yr}$ ago. Geology 25, 483-486.

Ashley, G.M., 1990. Classification of large-scale subaqueous bedforms: a new look at an old problem. Journal of Sedimentary Petrology 60, 160-172.

Barber, D.C., Dyke, A., Hillaire-Marcel, C., Jennings, A.E., Andrews, J.T., Kerwin, M.W., Bilodeau, G., McNeely, R., Southon, J., Morehead, M.D., Gagnon, J.-M., 1999. Forcing of the cold event of 8,200 years ago by catastrophic drainage of Laurentide lakes. Nature 400, 344-348.

Bard, E., Hamelin, B., Arnold, M., Montaggioni, L., Cabioch, G., Faure, G., Rougerie, F., 1996. Deglacial sea-level record from Tahiti corals and the timing of global meltwater discharge. Nature $382,241-244$.

Broecker, W.S., Kennett, J.P., Flower, B.P., Teller, J.T., Trumbore, S., Bonani, G., Woelfli, W., 1989. Routing of meltwater from the Laurentide ice sheet during the Younger Dryas cold episode. Nature 341, 318-321.

Butman, B., Middleton, T.J., Thieler, E.R., Schwab, W.C., 2003. Topography, Shaded Relief and Backscatter Intensity of the Hudson Shelf Valley, Offshore of New York. U.S. Geological Survey Open-File Report 03-372, 1 CD-ROM. 
Clark, P.U., Marshall, S.J., Clarke, G.K.C., Hostetler, S.W., Licciardi, J.M., Teller, J.T., 2001. Freshwater forcing of abrupt climate change during the last glaciation. Science 293, 283-287.

Dillon, W.P., Oldale, R.N., 1978. Late Quaternary sea-level curve: reinterpretation based on glaciotectonic influence. Geology 6, $56-60$.

Donnelly, J.P., Driscoll, N.W., Uchupi, E., Keigwin, L.D., Schwab, W.C., Thieler, E.R., Swift, S.A., 2005. Catastrophic meltwater discharge down the Hudson River valley: a potential trigger for the IntraAllerød Cold Period. Geology 33, 89-92.

Emery, K.O., Garrison, L.E., 1967. Sea levels 7000 to 20,000 years ago. Science 157, 684-687.

Emery, K.O., Uchupi, E., 1972. Western North Atlantic Ocean: Topography, Rocks, Structure, Water, Life, Sediment. American Association of Petroleum Geologists Memoir 17. American Association of Petroleum Geologists, Tulsa, Oklahoma. 532 pp.

Ewing, J., LePichon, X., Ewing, M., 1963. Upper stratification of Hudson Apron region. Journal of Geophysical Research 68, 6303-6316.

Fairbanks, R.G., 1989. A 17,000-year glacio-eustatic sea level record: influence of glacial melting rates on the Younger Dryas event and deep-ocean circulation. Nature 342, 637-642.

Fanning, A.F., Weaver, A.J., 1997. Temporal-geographical meltwater influences on the North Atlantic conveyor: implications for the Younger Dryas. Paleoceanography 12, 307-320

Fluhr, T.W., 1962. New York Bay-bedrock profile. Geological Society of America Bulletin 73, 261-262.

Ganopolski, A., Rahmstorf, S., 2001. Rapid changes of glacial climate simulated in a coupled climate model. Nature 409, 153-158.

Gaswirth, S.B., Ashley, G.M., Sheridan, R.E., 2002. Use of seismic stratigraphy to identify conduits for saltwater intrusion in the vicinity of Raritan Bay, New Jersey. Environmental and Engineering Geoscience 8, 209-218.

Kennedy, J.F., 1963. The mechanics of dunes and antidunes in erodible-bed channels. Journal of Fluid Mechanics 16, 521-544.

Knebel, H.J., Spiker, E.C., 1977. Thickness and age of surficial sand sheet, Baltimore Canyon Trough area. American Association of Petroleum Geologists Bulletin 61, 861-871.

Knebel, H.J., Wood, S.A., Spiker, E.C., 1979. Hudson River: evidence for extensive migration on the exposed continental shelf during Pleistocene time. Geology 7, 254-258.

Licciardi, J.M., Teller, J.T., Clark, P.U., 1999. Freshwater routing by the Laurentide ice sheet during the last deglaciation. In: Clark, P.U., Webb, R.S., Keigwin, L.D. (Eds.), Mechanisms of Global Climate Change at Millennial Time Scales. American Geophysical Union, Washington, pp. 177-201.

Liu, J.P., Milliman, J.D., Gao, S., Cheng, P., 2004. Holocene development of the Yellow River's subaqueous delta, North Yellow Sea. Marine Geology 209, 45-67.

Manabe, S., Stouffer, R.J., 1997. Coupled ocean-atmosphere model response to freshwater input: comparison to Younger Dryas event. Paleooceanography 12, 321-336.

Middleton, G.V., 1965. Antidune cross-bedding in a large flume. Journal of Sedimentary Petrology 35, 922-927.

Middleton, G.V., Hampton, M.A., 1976. Subaqueous sediment transport and deposition by sediment gravity flows. In: Stanley, D.J., Swift, D.J.P. (Eds.), Marine Sediment Transport and Environmental Management. Wiley, New York, pp. 197-218.

Milliman, J.D., Emery, K.O., 1968. Sea level during the past 35,000 years. Science 162, 1121-1123.

Milliman, J.D., Jiezao, Z., Anchun, L., Ewing, J.I., 1990. Late Quaternary sedimentation on the outer and middle New Jersey continental shelf: result of two local deglaciations? Journal of Geology 98, 966-976.

Muller, E.H., Prest, V.K., 1985. Glacial Lakes in the Ontario basin. In: Karrow, P.F., Calkin, P.E. (Eds.), Quaternary Evolution of the Great Lakes. Geological Association of Canada Special Paper, vol. 30, pp. 213-229.

Newman, W.S., Thurber, D.L., Zwiss, H.S., Rokach, A., Musich, L., 1969. Late Quaternary geology of the Hudson River estuary: a preliminary report. New York Academy of Sciences Transactions, Serial 2 (31), 548-570.

Pair, D.L., Rodrigues, C.G., 1993. Late Quaternary deglaciation of the southwestern St. Lawrence Lowland, New York and Ontario. Geological Society of America Bulletin 105, 1151-1164.

Poag, C.W., 1978. Stratigraphy of the Atlantic continental shelf and slope of the United States. Annual Review of Earth and Planetary Sciences 6, 251-280.

Rahmstorf, S., 1995. Bifurcations of the Atlantic thermohaline circulation in response to changes in the hydrological cycle. Nature 378, 145-149.

Rayburn, J.A., Knuepfer, P.L.K., Franzi, D.A., 2005. A series of large, Late Wisconsinan meltwater floods through the Champlain and Hudson Valleys, New York State, USA. Quaternary Science Reviews 24, 2410-2419.

Reineck, H.-E., Singh, I.B., 1980. Depositional Sedimentary Environments. Springer-Verlag, New York.

Richard, P.J.H., Occhietti, S., 2005. ${ }^{14} \mathrm{C}$ chronology for ice retreat and inception of Champlain Sea in the St. Lawrence Lowlands, Canada. Quaternary Research 63, 353-358.

Ridge, J.C., 1997. Shed Brook Discontinuity and Little Falls Gravel: evidence for the Erie interstade in central New York. Geological Society of America Bulletin 109, 652-665.

Ridge, J.C., Besonen, M.R., Brochu, M., Brown, S.L., Callahan, J.W., Cook, G.J., Nicholson, R.S., Toll, N.J., 1999. Varve, paleomagnetic and ${ }^{14} \mathrm{C}$ chronologies for Late Pleistocene events in New Hampshire and Vermont (U.S.A.). Géographie Physique et Quaternaire 53, 79-106.

Rodrigues, C.G., 1988. Late Quaternary invertebrate faunal associations and chronology of the western Champlain Sea Basin. In: Gadd, N.R. (Ed.), The Late Quaternary Development of the Champlain Sea Basin. Geological Association of Canada Special Paper, vol. 35, pp. 155-176.

Schwab, W.C., Allison, M.A., Corso, W., Lotto, L.L., Butman, B., Buchholtz ten Brink, M., Denny, J.F., Danforth, W.W., Foster, D.S., 1997a. Initial results of high-resolution sea-floor mapping offshore of the New York-New Jersey metropolitan area using sidescan sonar. Northeastern Geology and Environmental Sciences 19, 243-262.

Schwab, W.C., Corso, W., Allison, M.A., Butman, B., Denny, J.F., Lotto, L., Danforth, W.W., Foster, D.S., O’Brien, T.F., Nichols, D.A., Irwin, B.J., Parolski, K.F., 1997b. Mapping the sea floor geology offshore of the New York-New Jersey metropolitan area using sidescan sonar: preliminary report. U.S. Geological Survey Open-File Report 97-61. 3 map sheets.

Schwab, W.C., Thieler, E.R., Allen, J.R., Foster, D.S., Swift, B.A., Denny, J.F., 2000. Influence of inner-shelf geologic framework on the evolution and behavior of the barrier system between Fire Island Inlet to Shinnecock Inlet, Long Island, New York. Journal of Coastal Research 16, 408-422.

Schwab, W.C., Denny, J.F., Foster, D.S., Lotto, L.L., Allison, M.A., Uchupi, E., Swift, B.A., Danforth, W.W., Thieler, E.R., Butman, B., 2003. High-resolution Quaternary Seismic Stratigraphy of the New York Bight Continental Shelf. U.S. Geological Survey OpenFile Report 02-152, 1 DVD-ROM. 
Soren, J., 1971. Results of subsurface exploration in the mid-island area of western Suffolk County, Long Island, New York. Long Island Water Resources Bulletin, vol. 1. 60 pp.

Stanford, S.D., 1993. Late Cenozoic surficial deposits and valley evolution of unglaciated northern New Jersey. Geomorphology 7 , $267-288$

Stanford, S.D., Harper, D.P., 1991. Glacial lakes of the lower Passaic, Hackensack, and lower Hudson valleys, New Jersey and New York. Northeastern Geology 13, 271-286.

Suter, R., deLaguna, W., Perlmutter, N.M., 1949. Mapping of geologic formations and aquifers of Long Island, New York. State of New York Department of Conservation Water Power and Control Commission Bulletin GW-18. 212 pp.

Swift, D.J.P., Moir, R., Freeman, G.L., 1980. Quaternary rivers on the New Jersey shelf: relation of seafloor to buried valleys. Geology 8 , $276-280$

Teller, J.T., Leverington, D.W., Mann, J.D., 2002. Freshwater outbursts to the oceans from glacial Lake Agassiz and their role in climate change during the last deglaciation. Quaternary Science Reviews 21, 879-887.

Thompson, H.D., 1936. Hudson Gorge in the Highlands. Geological Society of America Bulletin 47, 1831-1848.
Twichell, D.C., Knebel, H.J., Folger, D.W., 1977. Delaware River: evidence for its former extension to Wilmington submarine canyon. Science 195, 483-485.

Uchupi, E., Driscoll, N., Ballard, R.D., Bolmer, S.T., 2001. Drainage of late Wisconsin glacial lakes and the morphology and late Quaternary stratigraphy of the New Jersey-southern New England continental shelf and slope. Marine Geology 172, 117-145.

Veatch, A.C., Smith, P.A., 1939. Atlantic Submarine Valleys of the United States and the Congo Submarine Valley. Geological Society of America Special Paper 7101 pp.

Weiss, D., 1974. Late Pleistocene stratigraphy and paleoecology of the lower Hudson River estuary. Geological Society of America Bulletin 85, 1561-1570.

Williams, S.J., 1976. Geomorphology, Shallow Subbottom Structure, and Sediments of the Atlantic Inner Continental Shelf off Long Island, New York. U.S. Army Corps of Engineers, Coastal Engineering Research Center, Technical Paper, vol. 76-2. 123 pp.

Williams, S.J., Duane, D.B., 1974. Geomorphology and Sediments of the Inner New York Bight Continental Shelf. U.S. Army Corps of Engineers, Coastal Engineering Research Center, Report TM-45. $81 \mathrm{pp}$. 